\title{
PENGARUH KETINGGIAN TEMPAT DAN JENIS TERHADAP PENYUSUTAN ROTAN
}

\section{EFFECT ALTITUDE AND SPECIES THE SHRINKAGE OF RATTAN}

\author{
M. Loiwatu \\ Jurusan Kehutanan Fakultas Pertanian Universitas Pattimura Ambon \\ Jl. Ir.M.Putuhena Kampus Poka Ambon 97237 \\ Penulis korespondensi email : meyche_loiwatu@yahoo.com
}

\begin{tabular}{|l|l|}
\hline Diterima : 6 Januari 2018 & Disetujui : 19 Februari 2018 \\
\hline
\end{tabular}

\begin{abstract}
Intisari
Penelitian ini mengkaji tentang penyusutan tiga jenis rotan yaitu rotan Tohiti (Calamus inops Becc), Batang Air (Daemonorops robustus Warb), Manau (Calamus manan Miq). Dua faktor yang diteliti yaitu ketinggian tempat tumbuh $(<100 \mathrm{~m}, 100-200 \mathrm{~m},>200 \mathrm{~m})$ dan jenis rotan. Hasil penelitian menunjukan bahwa jenis rotan berpengaruh terhadap penyusutan dari kondisi segar ke kering udara. Ketinggian tempat berpengaruh terhadap penyusutan dari kondisi segar ke kering oven. Penyusutan volumetri kondisi segar ke kondisi kering udara berkisar antara 1,25\% sampai dengan 7,43\% dan Penyusutan volumetri kondisi kering udara ke kering oven berkisar antara 0,37 \% sampai dengan $1,81 \%$..
\end{abstract}

Kata kunci: rotan, susut,

\begin{abstract}
Objective of the study was to determine shrinkage of three species of rattan, such as Tohiti (Calamus inops Becc), Batang Air (Daemonorops robustus Warb), Manau (Calamus manan Miq). Two factors was applied in the study was growing site $(<100 \mathrm{~m}, 100-200 \mathrm{~m}$, $>200 \mathrm{~m}$ ) and species of rattan. Result of the study indicated that species of rattan was affected the shrinkage from green to air dry condition. Growing site was affected the shrinkage green to oven dry condition. Shrinkage from green to air dry condition was $1.25 \%$ $-7.43 \%$ and shrinkage from air dry to oven dry condition was $0.37 \%-1.81 \%$.
\end{abstract}

\section{Keywords : rattan, shrinkage.}

\section{PENDAHULUAN}

Rotan merupakanjenis tanaman family Palmae yang tumbuh memanjat dan banyak tersebar di bagian bumi beriklim tropis dan sub tropis. Keanekaragaman jenis rotan banyak di jumpa di Asia tenggara dan merupakan komuditas penting setelah kayu. Indonesia adalah Negara penghasil rotan terbesar di Dunia. Luas hutan di Indonesia sebesar 13,20 juta hektar tergolong ke dalah 8 marga dan 306 jenis, daripadanya 51 jenis yang telah dimanfaatkan. Jenis yang memiliki nilai harga jual yang paling tinggi adalah jenis Calamus dan Daemonorops yang terdapat juga di Maluku. Maluku memiliki potensi rotan yang cukup besar dengan luasan 2.905.750 Ha dengan 11 jenis yang dimanfaatkan (Kasmudjo, 2012) dan setiap tahun dihasilkan rotan sebesar 629.829 ton (Anonim, 2010). 
Rotan termasuk tumbuhan berkayu karena memiliki jaringan pengangkutan yang disebut xylem dan phloem. Struktur anatomi rotan lebih sederhana bila dibandingkan dengan struktur anatomi kayu. Rotan tidak memiliki unsur sel yang berarah trasversal sehingga rotan mudah dibelah dan bersifat elastis artinya dapat dilengkungkan sampai batas tertentu tanpa mengalami kerusakan.

Rotan termasuk tumbuhan khas di daerah tropis yang secara alami tumbuh pada hutan primer maupun hutan sekunder, daerah perladangan berpindah dan belukar. Secara umum rotan dapat tumbuh pada berbagai keadaan seperti: di rawa, tanah kering, dataran rendah, pengunugan, tanah kering berpasir, tanah liat berpasir yang secara periodik digenangi air atau sama sekali bebas dari genangan air, jenis tanah latosol dan regosol. Pertumbuhan terbaik pada daerah -daerah lereng bukit yang cukup lembab dengan ketinggian antara $0-2900 \mathrm{~m}$ di atas permukaan laut, memiliki iklim basah sampai kering.

Penyusutan termasuk salah satu sifat fisis yang turut mempengaruhi kekuatan dan kualitas rotan. Produk dengan bahan baku rotan membutuhkan kestabilan dimensi yang tempat sehingga perubahan bentuk (penyusutan volumetrik) diharapkan tidak terjadi atau seminimal mungkin. Pengetahuan tentang nilai penyusutan volumetri dapat menjadi solusi untuk memperhatikan proses pengolahannya sehingga kualitas dapat ditingkatkan.

\section{METODE PENELITIAN}

\section{Lokasi dan Waktu Penelitian}

Sampel rotan diambil pada Desa Weer Kecamatan Kei Besar Timur Kabupaten Maluku Tenggara. Lamanya waktu pengambilan selama \pm 2 minggu di lapangan dilanjutkan pengujian sifat fisik di Laboratorium Teknologi Kayu Fakultas Pertanian Universitas Pattimura Ambon. Penelitian ini berlangsung selama 2 bulan dari tanggal 23 September 24 November 2016. Peralatan yang digunakan dalam penelitian ini adalah : GPS, parang, sarung tangan, gergaji, timbangan analitik, statip, gelas ukur, oven, desikator, jepitan, kwas, Jarum, kamera digital dan alat tulis menulis. Bahan yang digunakan dalam penalitian ini yaitu rotan tohiti (Calamus inops, Becc), batang air (Daemonorops robustus, Warb), dan Manau (Calamus manan, Miq), paraffin cair dan aquades.

\section{Prosedur Penelitian}

Pembuatan contoh uji dan pengujian penyusutan rotan dilakukan mengacu pada Standar Nasional Indonesia (SNI 01-7254-2006).
Cara Pengambilan Sampel Penyusutan Volumetri 
Penentuan lokasi pengambilan sampel penyusutan ditentukan dengan pengamatan secara visual setiap rotan yang diambil untuk mengetahui jenisnya. Batang rotan ditebang setelah itu dibebaskan dari duri dan ranting pada rotan. Batang rotan bebas duri dan ranting

\section{1) Potongan Uji Penyusutan Volumetri}

Potongan uji dibuat untuk melakukan uji laboratoris (penyusutan volumetri). Potongan uji diambil dari
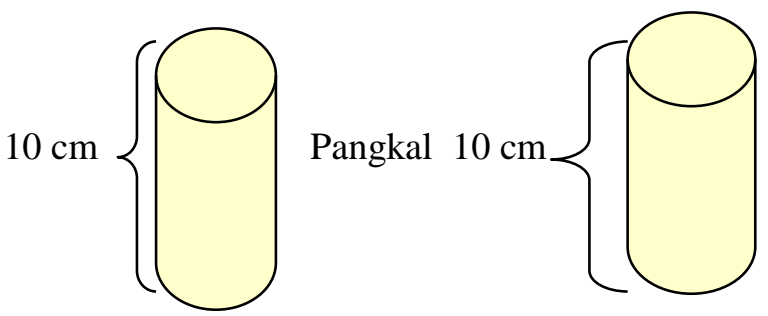

diukur panjangnya, ditentukan bagianbagian rotan yang mewakili bagian pangkal, tengah dan ujung. Batang rotan di potong sesuai dengan kebutuhan penelitian yakni pangkal $10 \mathrm{~cm}$, tengah $10 \mathrm{~cm}$, dan ujung $10 \mathrm{~cm}$.

tiap jenis rotan dengan jumlah contoh uji sebanyak 3 buah pada bagian pangkal, tengah, ujung, dengan ukuran panjang $10 \mathrm{~cm}$.

\section{Gambar 1. Potongan contoh uji rotan}

Pembuatan contoh uji dilakukan pada saat kondisi rotan baru selesai ditebang (kondisi segar).

\section{2) Ukuran Contoh Uji Penyusutan Volumetri}

Contoh uji berukuran panjang $10 \mathrm{~cm}$
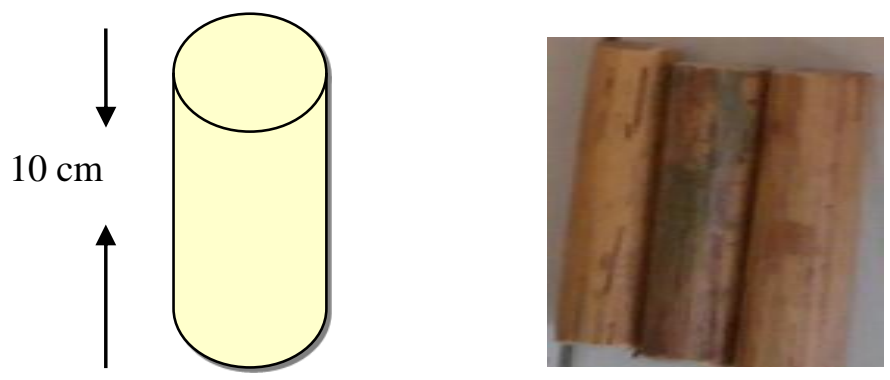

\section{Gambar 2. Contoh Uji Penyusutan Volumetri}

Penyusutan terjadi apabila rotan dalam keadaan segar dikeringkan sampai kering oven maka air dalam rotan akan menguap. Penguapan ini dimulai dari air bebas dalam rongga sel keluar hingga mencapai titik jenuh serat dan air terikat dalam dinding sel berangsur-angsur mulai keluar. Titik jenuh serat adalah titik dimana semua air didalam 
rongga sel telah keluar tetapi dinding sel masih jenus dengan air (Haygreen dan Bowyer, 1989). Penelitian ini menghitung penyusutan volumetrik rotan dari kondisi segar ke kering udara dan kondisi kering udara ke kering oven.

\section{Cara Kerja :}

1. Menyiapkan contoh uji rotan dengan panjang $10 \mathrm{~cm}$ dan dilaburi paraffin cair serta diangin-anginkan hingga paraffin tidak menetes.

2. Gelas ukur diisi dengan aquades kemudian ditimbang dan dicatat beratnya (A)

3. Contoh uji dimasukkan ke dalam gelas ukur dengan bantuan jarum panjang yang ada di statip hingga seluruh bagian rotan terendam tetapi tidak menyentuk dinding gelas ukur dan tidak menimbulkan gelembung.
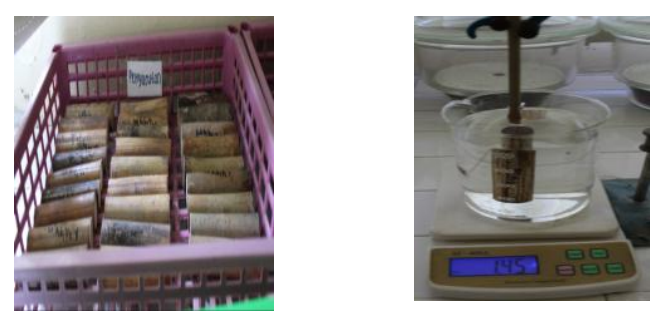

\section{Gambar 2. Contoh Uji Penyusutan Volumetri dan Pengujian Volume Rotan}

4. Gelas ukur dan contoh uji tersebut ditimbang beratnya dan dicatat (B)

5. Dilakukan perhitungan selisih berat (B-A), nilai selisih berat tersebut merupakan berat air yang nilainya sama dengan VOLUME ROTAN SEGAR.

6. Contoh uji dikeluarkan dan dianginanginkan pada kondisi udara dan ditimbang terus menerus beratnya hingga beratnya konstan pada kondisi kering udara. Contoh uji dilaburi paraffin cair dan dibiarkan hingga tidak ada tetasan lagi.

7. Gelas ukur diisi dengan aquades kemudian ditimbang dan dicatat beratnya $(\mathrm{A})$
8. Contoh uji dimasukkan ke dalam gelas ukur dengan bantuan jarum panjang yang ada statip hingga seluruh bagian rotan terendam tetapi tidak menyentuk dinding gelas ukur dan tidak menimbulkan gelembung.

9. Gelas ukur dan contoh uji tersebut ditimbang beratnya dan dicatat (B)

10. Dilakukan perhitungan selisih berat (B-A), nilai selisih berat tersebut merupakan berat air yang nilainya sama dengan VOLUME ROTAN KERING UDARA.

11. Rotan dikeluarkan dan dianginanginkan hingga air tidak menetes lagi. Contoh uji rotan dimasukkan dalam oven pada suhu $103 \pm 2^{\circ} \mathrm{C}$ selama 3 jam. Contoh uji keluarkan, 
dimasukkan dalam desikator dan ditimbang. Perlakuan ini dilakukan terus menerus hingga beratnya konstan. Contoh uji dilaburi paraffin cair dan dibiarkan hingga tidak menetes.

12. Gelas ukur diisi dengan aquades kemudian ditimbang dan dicatat beratnya $(\mathrm{A})$

13. Contoh uji dimasukkan ke dalam gelas ukur dengan bantuan jarum panjang

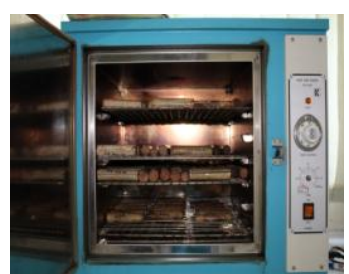

(A)

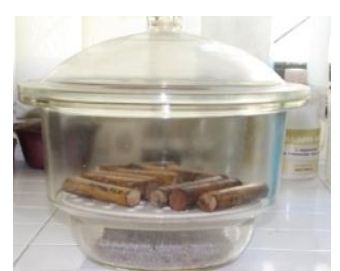

(B) yang ada statip hingga seluruh bagian rotan terendam tetapi tidak menyentuk dinding gelas ukur dan tidak menimbulkan gelembung.

14. Gelas ukur dan contoh uji tersebut ditimbang beratnya dan dicatat (B)

15. Dilakukan perhitungan selisih berat (B-A), nilai selisih berat tersebut merupakan berat air yang nilainya sama dengan VOLUME ROTAN KERING OVEN.

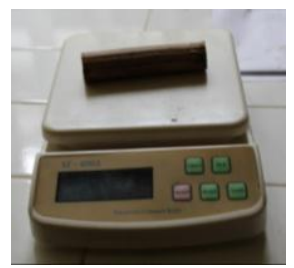

(C)

Gambar 3. (A). Contoh uji di dalam oven pengering.

(B). Contoh uji di dalam desikator

(C). Penimbangan berat contoh uji

Penentuan perhitungan penyusutan volumetri rotan kondisi segar ke kering udara menggunakan rumus :

Penyusutan Volumeteri rotan kondisi Segar ke $\mathrm{Ku}=\frac{\mathrm{Vs}-\mathrm{VKu}}{\mathrm{Vs}} \mathbf{1 0 0} \%$

Keterangan :

Vs $=$ Volume Rotan Kondisi Segar

VKo $=$ Volume Rotan Kondisi Kering Udara

Penentuan penyusutan volumetri rotan kondisi kering udara ke kering oven menggunakan rumus :

Penyusutan Volumetri rotan kondisi $\mathrm{Ku}$ ke Ko $=\frac{\mathbf{V K u}-\mathbf{V K o}}{\mathbf{V K u}} \mathbf{1 0 0} \%$ Keterangan :

$$
\begin{aligned}
\text { VKu }= & \text { Volume Rotan Kondisi Kering } \\
& \text { Udara } \\
\text { VKo = } & \text { Volume Rotan Kondisi Kering } \\
& \text { Oven }
\end{aligned}
$$

\section{Analisis Data}

Rancangan percobaan yang digunakan adalah Rancangan Acak Lengkap (Gaspersz, 1989), dengan percobaan faktorial yang mengunakan 3 ulangan. Dengan ulangan faktorial 3 x 3 x 3 sehingga total perlakuan sebayak 27 satuan dengan dua faktor yaitu :

Faktor $\mathrm{A}=$ Ketinggian tempat tumbuh terdiri dari tiga tingkatan :

$$
\mathrm{a} 1=0-<100 \mathrm{~m} \mathrm{dpl}
$$




$$
\begin{aligned}
& \mathrm{a} 2=100-200 \mathrm{~m} \mathrm{dpl} \\
& \mathrm{a} 3=>200 \mathrm{~m} \mathrm{dpl}
\end{aligned}
$$

Faktor B = Jenis rotan terdiri dari 3 tingkatan:

b1 = Tohiti (Calamus inops, Becc)

b2 = Batang air (Daemonorops robustus, Warb)

b3 = Manau (Calamus manna, Miq)

Model matimatisnya sebagai berikut :

$$
\mathbf{Y}_{\mathrm{ijk}=\mu}+\alpha_{\mathrm{i}}+\beta_{\mathrm{j}}+(\alpha \beta) \mathbf{i}_{\mathrm{j}}+\varepsilon_{\mathrm{ijk}}
$$

Dimana :

$\mathbf{Y}_{\mathbf{i j k}}=$ Nilai pengamatan dari taraf ke ifaktor $\alpha$, taraf ke j faktor $\beta$

$\boldsymbol{\mu}=$ Nilai rata- rata yang sesungguhnya

$\boldsymbol{\alpha}_{\mathbf{i}} \quad=$ Pengaruh dari taraf ke i - faktor $\alpha$

$\boldsymbol{\beta}_{\mathbf{j}} \quad=$ Pengaruh dari taraf ke $\mathrm{i}-$ faktor $\beta$ $\boldsymbol{\alpha} \boldsymbol{\beta}) \mathbf{i}_{\mathbf{j}}=$ Pengaruh Interaksi taraf ke i faktor $\alpha$ dan taraf $k e-j$ faktor $\beta$

Hasil analisis keragaman menunjukan hubungan yang nyata atau sangat nyata maka dilanjutkan dengan Uji Beda Nyata jujur (BNJ) untuk melihat hubungan antara masing-masing perlakuan, rumus $\mathrm{BNJ}$ adalah sebagai berikit:

Dimana :

$$
\mathrm{W}=\mathbf{Q} \alpha(\mathrm{p}, \mathrm{db} \text { Galat }) \frac{\sqrt{K T A}}{r}
$$

$\mathbf{Q} \boldsymbol{\alpha}=$ Diperoleh dari table untuk tingkat $5 \%$ dan $1 \%$

$\mathrm{p} \quad=$ Jumlah perlakuan

$\mathbf{r} \quad=$ Ulangan

KTA $=$ Kuadrat tengah acak

\section{HASIL DAN PEMBAHASAN}

Rotan mengalami perubahan dimensi pada saat terjadi penghilangan dan penambahan air, yang dinyatakan sebagai penyusutan dan pengembangan. Jika rotan kehilangan air dibawah titik jenuh serat (TJS) yaitu air terikat maka rotan akan menyusut. Penyusutan terjadi saat molekul-molekul air terikat melepaskan diri dari antara molekul-molekul selulosa berantai panjang dan molekul-molekul hemiselulosa, mengakibatkan molekulmolekul ini bergerak saling mendekat. Hasil pengamatan penyusutan rotan berdasarkan ketinggian tempat dan posisi aksial tiga jenis rotan pada kondisi segar sampai kering oven disajikan pada Tabel 1.

Tabel 1. Penyusutan volumetri tiga jenis rotan berdasarkan ketinggian tempat tumbuh

\begin{tabular}{cccccccc}
\hline \multirow{2}{*}{ Sifat Fisis } & \multicolumn{2}{c}{ Perlakuan } & & Ulangan & & Total & Rataan \\
& $\begin{array}{c}\text { Ketinggian } \\
\text { Tempat Tumbuh }\end{array}$ & Jenis & & & & & \\
\cline { 2 - 8 } & 91 mdpl & B1(Tohiti) & 4,41 & 3,33 & 6,87 & 14,61 & 4,87 \\
(A1) & B2 (B.Air) & 3,81 & 1,25 & 1,45 & 6,51 & 2,17 \\
\hline
\end{tabular}




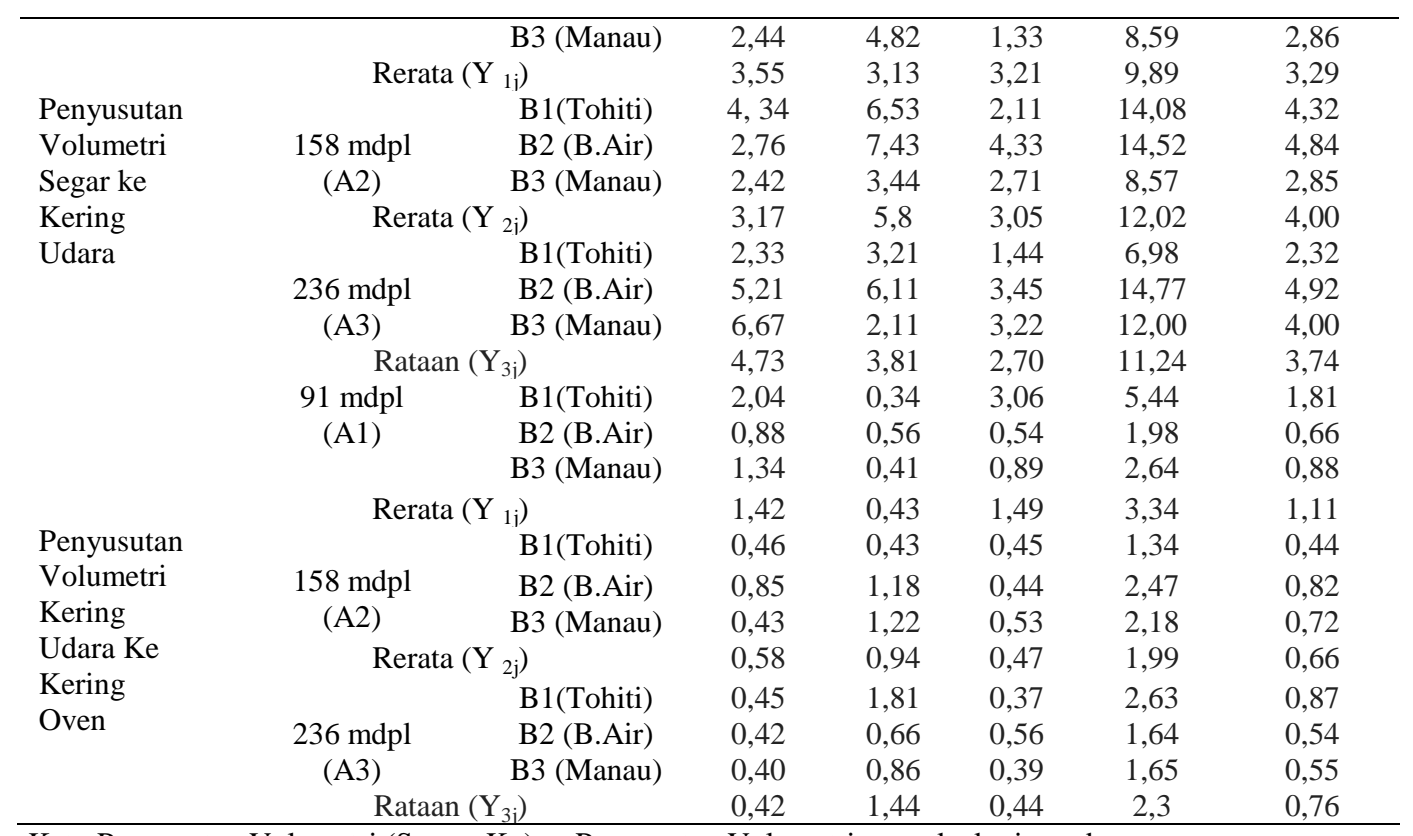

Ket : Penyusutan Volumetri (Segar- $\mathrm{Ku})$ = Penyusutan Volumetri segar ke kering udara

Penyusutan Volumetri (KU-KO) = Penyusutan Volumetri Kering udara ke kering oven

Besarnya penyusutan rotan sebanding dengan besarnya air yang keluar dari dinding sel sehingga rotan dengan berat jenis yang tinggi akan menyusut lebih banyak dan sebaliknya. Nilai penyusutan volumetri dari kondisi segar sampai kering udara hingga kering oven meningkat dari pangkal hingga ujung batang rotan searah dengan trand kadar air didalamnya namun berbanding terbalik dengan nilai berat jenis.

\section{Penyusutan volumetri rotan kondisi segar ke kering udara}

Penyusutan rotan merupakan Penyusutan dinding sel terjadi saat molekul-molekul air terikat melepaskan diri dari molekul-molekul selulosa berantai panjang dan molekul-molekul hemiselulosa yang kemudian bergerak saling mendekat. Banyaknya penyusutan yang terjadi umumnya sebanding dengan jumlah air yang keluar dari dinding sel.
Pengembangan secara sederhana adalah kebalikan proses ini. Penyusutan dan pengembangan dinyatakan sebagai persen dimensi sebelum perubahan terjadi. Penyebab utama penyusutan adalah jaringan serat dalam berkas pembuluh kehilangan air. Sebagai akibat, penyusutan makin tinggi dengan banyaknya air yang dikeluarkan dari dalam berkas pembuluh atau tingkat kekeringannya rendah. Menurut Liese (1985), penyusutan dimulai secara simultan dengan berkurangnya kadar air, namun tidak berlangsung terusmenerus. Setelah mencapai kadar air $40 \%$, penyusutan akan berhenti dan mulai lagi ketika kadar air sudah mendekati titik jenih serat $(25 \%-30 \%)$.

Pada nilai penyusutan volume dari kondisi segar ke kering udara yang diperoleh pada berbagai ketinggian tempat 
tumbuh, kemudian dilakukan analisis varians untuk mengetahui faktor-faktor yang mempengaruhinya (Tabel 2).

Tabel 2. Analisis varians penyusutan volumetri rotan pada kondisi segar ke kering udara

\begin{tabular}{ccccccc}
\hline $\begin{array}{c}\text { Sumber } \\
\text { keragama }\end{array}$ & $\mathrm{db}$ & $\mathrm{JK}$ & $\mathrm{KT}$ & $\mathrm{F} . \mathrm{Hit}$ & $\mathrm{F}_{0,05}$ & $\mathrm{~F}_{0,01}$ \\
\hline A & 2 & 362,30 & 181,15 & $21,59 * *$ & 3,55 & 6,01 \\
B & 2 & 322,63 & 161,31 & $19,22 * *$ & 3,55 & 6,01 \\
AxB & 4 & 448,07 & 112,01 & $13,35 * *$ & 2,93 & 4,58 \\
Galat & 18 & 151,08 & 8,39 & & \\
Total & 26 & 85,78 & & & \\
\hline
\end{tabular}

Ket : $* *=$ sangat nyata

Analisis varians penyusutan volumetri kondisi segar ke kering udara (Tebal 2) menunjukkan bahwa ketinggian tempat, jenis rotan dan interaksinya memberikan pengaruh yang sangat nyata terhadap penyusutan volumetri. Hal ini dikarena faktor kadar air dan berat jenis turut menentukan variasi penyusutan volumetri yang terjadi. Besar kecilnya penyusutan setimbang dengan jumlah air yang dilepaskan atau dikeluarkan dari dinding sel. Banyaknya air yang dilepaskan maka penyusutan volumetri yang terjadi juga besar dan apabila air yang dilepaskan sedikit maka penyusutan volumetri kecil. Untuk mengetahui lebih lanjut pengaruh ketinggian tempat terhadap penyusutan volumetri rotan dari kondisi segar ke kering udara maka dilakukan uji BNJ dan hasilnya disajikan pada tabel berikut ini.

Tebel 3. Uji BNJ Penyusutan volumetri rotan kondisi segar untuk ketinggian tempat

\begin{tabular}{cccc}
\hline Perlakuan & Rataan & Beda \\
\hline A1 & 3,29 & & \\
A2 & 4,06 & $0,77^{*}$ & \\
A3 & 3,74 & $0,45^{*}$ & $0,32^{*}$ \\
\hline
\end{tabular}

Hasil uji BNJ pada tabel 3 menunjukkan bahwa penyusutan volumetri rotan berdasarkan ketinggian tempat tumbuh tertinggi pada perlakuan ketinggian tempat (a2) 100-200 mdpl yaitu sebesar $4,06 \%$ diikuti oleh ketinggian tempat < 100 mdpl (a1) yaitu sebesar $3,24 \%$, dan terendah pada ketinggian tempat > 200 mdpl (a3) yaitu sebesar
$3,46 \%$. Ketinggian tempat tumbuh rotan turut menentukan kandungan masa kayu. Masa kayu yang tinggi akan memiliki jumlah air dan penyusutan yang kecil. Semakin rendah nilai kadar air dan penyusutan volumetri maka semakin tinggi berat jenis rotan atau masa kayu asalkan kandungan ekstraktif tidak menghalangi. Menurut Oey Djoen Seng (1990), variasi 
berat jenis dipengaruhi oleh kecepatan berhubungan dengan faktor lingkungan tumbuh. Kecepatan tumbuh ini tempat tumbuh.

Tabel 4. Uji BNJ Penyusutan volumetri berdasarkan jenis rotan

\begin{tabular}{cccc}
\hline Perlakuan & Rataan & \multicolumn{2}{c}{ Beda } \\
\hline B1 & 3,81 & & \\
B2 & 4,24 & $8,05^{* *}$ & \\
B3 & 2,98 & $6,79^{* *}$ & $7,22^{* *}$ \\
\hline
\end{tabular}

Hasil uji BNJ berdasarkan jenis rotan terlihat bahwa jenis batang air (Daemonorops robustus, Warb) menyusut lebih tinggi sebesar 4,24\%, diikuti jenis Tohiti (Calamus inops, Becc) sebesar 3,81\% dan terendah jenis Manau (Calamus manna, Miq) sebesar 2,98\%. Jenis yang menyusut lebih kecil memiliki kestabilan dimensi yang lebih tinggi dan sebaliknya.
Kestabilan dimensi berkaitan dengan kekuatan rotan. Rotan yang mudah stabil memiliki kekuatan dan masa kayu yang lebih tinggi.

Hubungan antara ketinggin tempat tumbuh (A) dan jenis rotan (B) terhadap penyusutan volumetri pada kondisi segar ke kondisi kering udara dapat dilihat pada grafik dibawah ini.

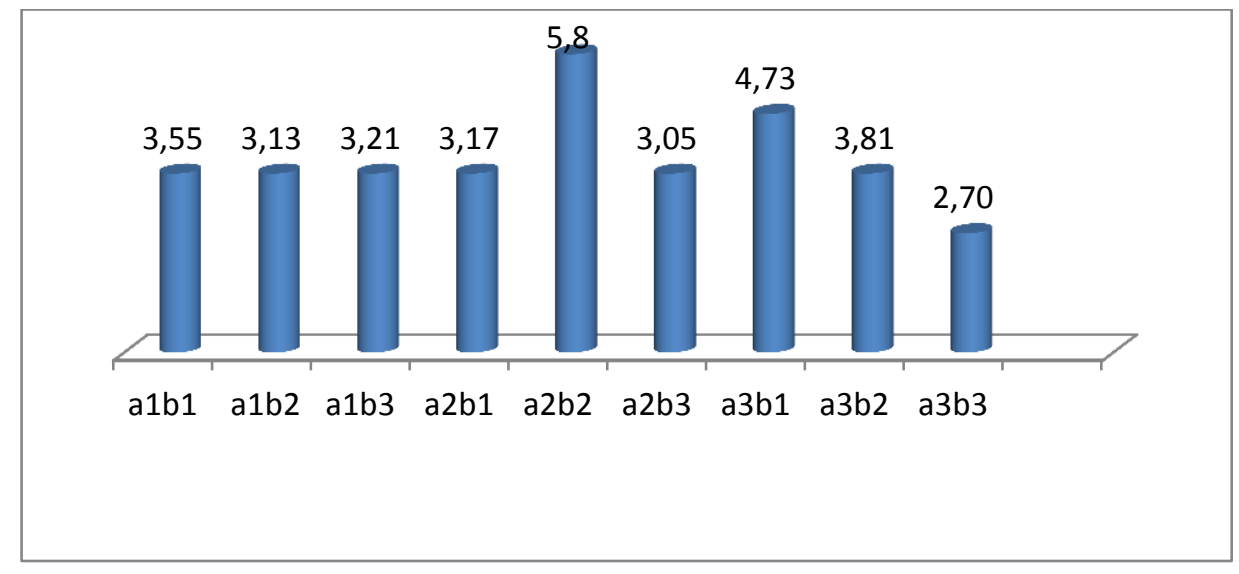

Gambar 4 : Grafik hubungan antara ketinggian tempat dan jenis rotan terhadap Penyusutan volumetri dari kondisi segar ke kering udara

Penyusutan volumetrik tertinggi pada perlakuan a2b2 (ketinggian tempat tumbuh 100-200 $\mathrm{m} \mathrm{dpl} \mathrm{dg} \mathrm{jenis} \mathrm{rotan}$ batang air), diikuti oleh perlakuan a3b1(ketinggian tempat tumbuh >200 mdpl dengan jenis tohiti) dan terendah pada perlakuan a3b3 (ketinggian tempat > $200 \mathrm{~m}$ dpl dengan jenis rotan manau).

Penyusutan berkaitan juga dengan struktur anatomi rotan diantaranya berkas vascular. Semakin banyak berkas vascular semakin kuat kekuatan dan rendahnya penyusutan volumetri yang terjadi. Penyusutan yang rendah dapat direkomendasikan yang terbaik karena 
memiliki kestabilan dimensi dan kekuatan yang tinggi.

Gambar 6 memperlihatkan bahwa secara anatomi rotan memiliki unsur unsur longitudinal yaitu sel - sel yang arah panjangnya searah sumbuh panjang batang dan sebenarnya rotan tidak memiliki unsur - unsur yang berarah transversal seperti hanya unsur- unsur transversal pada kayu yang terdiri atas sel parenkim jari-jari dan sel epitel. Manuhuwa (2006), Apabila dibandingkan dengan struktur kayu daun lebar, struktur rotan jauh lebih sederhana karena hanya memiliki beberapa macam sel dan susunan sel ini lebih seragam. Hal ini terjadi karena rotan tidak memiliki sel yang berarah transversal maka rotan mudah dibelah dan bersifat elastis artinya dapat dilengkungkan sampai batas tertentu tanpa mengalami kerusakan dan muda mengalami penyusutan dan faktor - faktor yang dijelakan diatas sangat berpengaruh terhadap berat jenis rotan itu sendiri.
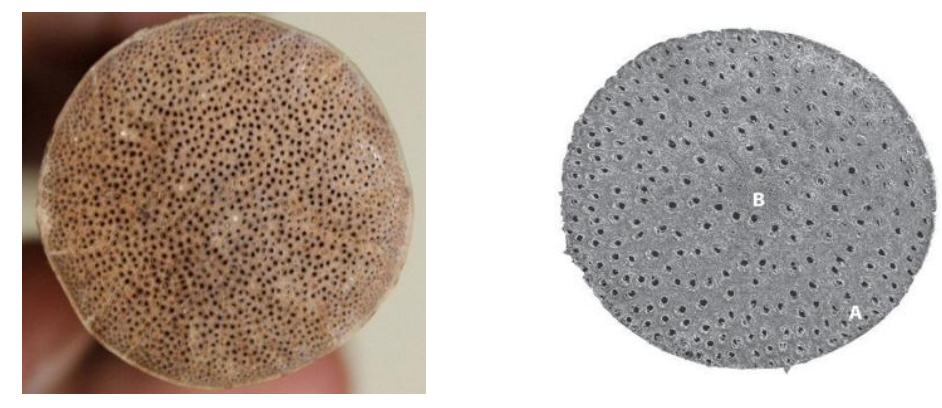

Gambar 5. Penampang Melintang Batang Vaskular

A) Wilayah luar atau korteks

B) Daerah dalam atau silinder pusat
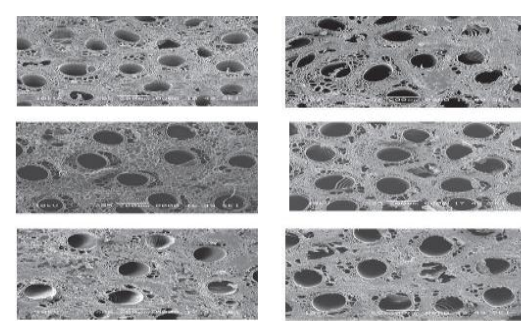

a). Wilayah luar atau korteks
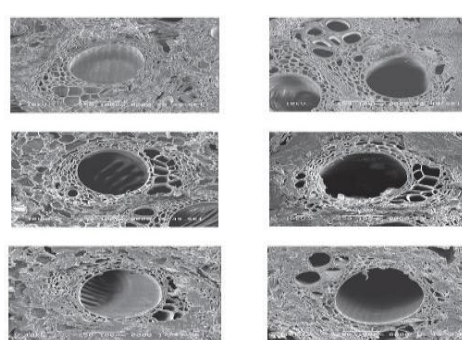

b).Daerah dalam atau silinder pusat

Gambar 6. Penampang Melintang Batang Vaskular : a) wilayah luar atau korteks, dan b) daerah dalam atau silinder pusat.

Pada diagram vascular batang rotan dapat dilihat adanya 2 (dua) bagian struktur yang berbeda walaupun batangnya tidak jelas. Hal ini disebabkan oleh lapisan luar yang relatif lebih padat dibandingkan bagian dalam yang terlihat jarang sedangkan bagain luar yang terlihat padat dinamakan korteks atau jaringan perifer sedangkan bagian dalam yang terlihat jarang yang relatif lebih lunak dinamakan 
jaringan sentral (Krisdianto dan Jasni (2005). Ketebalan jaringan parifer dapat berbeda dari jenis rotan yang satu terhadap jenis rotan yang lain. Agar labih jelas untuk melihat perbedaan di antara ke dua bagain struktur yang terlihat berbada diatas maka dapat dilihat pada gambar yang dibawa ini.

Gambar 7 memperlihatkan ketebalan jaringan parifer dapat berbeda dari jenis rotan yang satu ke jenis rotan
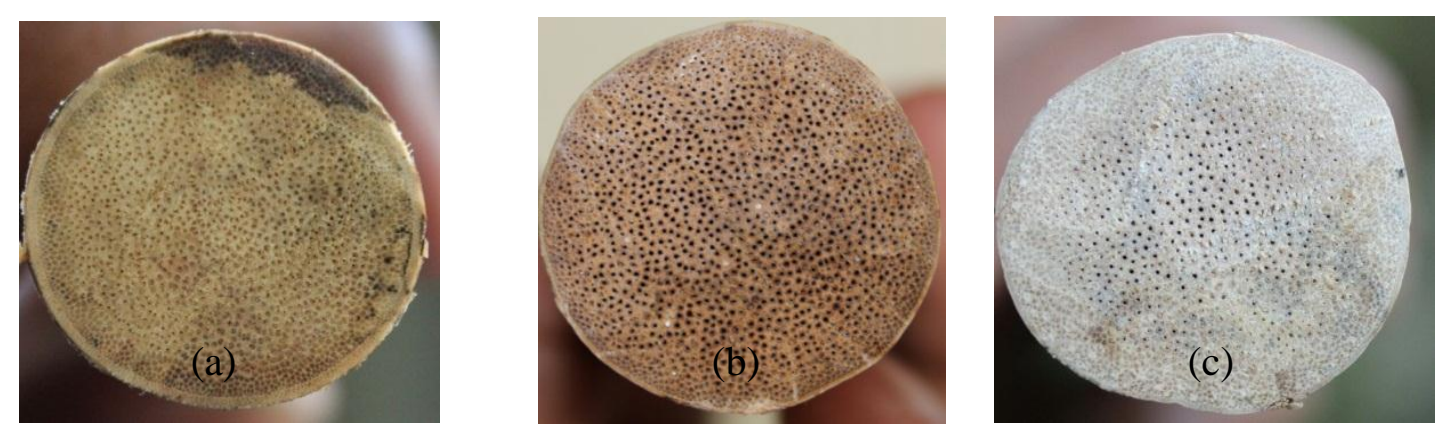

Gambar 7. Vascular Rotan tohiti (a) Rotan batang air (b) dan Rotan manau (c)

\section{Penyusutan Volume pada Kondisi Kering Udara ke Kering Oven}

$$
\text { Penyusutan volume yang terjadi }
$$
pada kondisi kering udara hingga kering oven diindikasikan dipengaruhi oleh keluarnya air yang ada di dalam dinding sel hingga pada kondisi kering oven dimana air dalam dinding sel hampir tidak yang lainnya. Hal ini bisa yang membuat berat jenis dan penyusutan volumetri antar satu jenis rotan dan jenis rotan lain berbeda. Berat jenis yang tinggi akan menghasilkan penyusutan volumetri yang rendah. 


\begin{tabular}{ccccccc} 
B & 2 & 33,15 & 16,57 & 3,49 tn & 3,55 & 6,01 \\
AxB & 4 & 41,73 & 10,43 & 2,20 tn & 2,93 & 4,58 \\
Galat & 18 & 85,26 & 4,74 & & & \\
Total & 26 & 66,38 & & & \\
\hline Ket $: * *$ Sangat Nyata $*$ Nyata & tn = Tidak Nyata
\end{tabular}

Analisis varians menunjukkan bahwa ketinggian tempat tumbuh rotan, jenis dan interaksinya tidak memberikan pengaruh terhadap penyusutan kondisi kering udara ke kering oven.

\section{KESIMPULAN}

1. Penyusutan volumetri kondisi segar ke kondisi kering udara berkisar antara $1,25 \%$ sampai dengan $7,43 \%$.

2. Penyusutan volumetri kondisi kering udara ke kering oven berkisar antara $0,37 \%$ sampai dengan $1,81 \%$.

3. Ketinggian tempat tumbuh (A) dan jenis rotan (B) berpengaruh terhadap penyusutan volumetri kondisi segar ke kering udara
4. Interaksi ketinggian tempat (A) dan Jenis rotan (B) berpengaruh terhadap penyusutan volumetri kondisi segar ke kering udara.

5. Ketinggian tempat (A), jenis rotan (B) dan interaksinya (AB) pada kondisi kering udara ke kering oven tidak memberikan pengaruh terhadap penyusutan volumetri.

\section{DAFTAR PUSTAKA}

Anonim

2010.

Rottan.

http://id.wikipedia.org/wiki/rotan.

Diakses pada tanggal 16 April 2016.

Dransfield, J. \& Monokara. 1996. Sumber Daya Nabati Asia Tenggara. No.6. Yogyakarta. Gadjah Mada UniversityPress.hlm.18-23.

Gaspersz, Z.1989. Metode perancagan untuk ilmu - ilmu pertanian dan ilmu- ilmu Teknik dan Biologi. Penerbit ARMICO

Haygreen, J.G dan J.L. Bowyer, 1996. Hasil hutan dan ilmu kayu. Terjemahan Gadjah Mada university Press, Yogyakarta.

Januminro, 2004. Rotan Indonesia. Kanisius, Yogyakarta.
Kasmudjo, 2012. Rotan dan bambu kelapa, kelapa sawit, Nipah, sagu, Penerbit: Cakrawala. Media, Jogjakarta.

Krisdianto dan jasni, 2005. Struktur Anatomi Tiga Jenis Batang Rotan. Jurnal Ilmu dan Teknologi Kayu Tropis.

Liese, W and G. Weiner, 1987. Anatomical structures for the identification of rottan. In : Rad, A.N and I. vongkaluang (eds). Proceeding International Seminar On Rottan. Kualalumpur, October 2-4, 1994.

Manuhuwa, E. 2006. Bahan Kulia Hasil Hutan Non Кауи (Bambu I-III). Jurusan Kehutanan Fakultas Pertanian Universitas Pattimura Ambon.

Oey-djeon-seng, 1990. Berat Jenis Dari Jenis - Jenis kayu Indonesia Pengertian Beratnya Kayu untuk Keperluan 
Praktek. Diterjemahkan oleh Pengembagan Hasil Hutan, Bogor. Soewarsono P.H, 1990. Pusat dan 